\title{
Podpułkownik Rudolf Ksieniewicz (1898-1940) - kawaler Orderu Virtuti Militari i ofiara zbrodni katyńskiej. Przyczynek do biografii
}

\begin{abstract}
Streszczenie. Artykuł przedstawia sylwetkę ppłk. Rudolfa Ksieniewicza, jednego z oficerów wojska Drugiej Rzeczypospolitej. Urodzony na estońskiej wyspie Dago, po przeprowadzce z rodziną zamieszkał w głębi Rosji. Aby ulżyć finansowo rodzicom, wstąpił do armii rosyjskiej. Pnąc się po szczeblach kariery, został w końcu jednym z organizatorów Wojska Polskiego na Syberii. W wyniku walk dostał się do niewoli bolszewickiej, w której pozostawał do października $1921 \mathrm{r}$. W wolnej Polsce kontynuował karierę wojskowego, osiągając stopień podpułkownika i stanowisko I zastępcy dowódcy 45 pułku piechoty w Równem na Wołyniu. W 1939 r. po mobilizacji 13 Dywizji Piechoty pozostał w Równem, którego został komendantem garnizonu. Po wkroczeniu Armii Czerwonej 17 września dostał się do niewoli i wiosną 1940 r. został zamordowany przez Sowietów w bliżej nieznanych okolicznościach.
\end{abstract}

Słowa kluczowe: Rudolf Ksieniewicz, Stefan Hojnowski, 45 pułk piechoty, Wojsko Polskie, zbrodnia katyńska, Równe, historia Równego, Katyń.

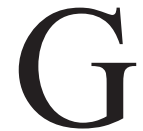
dy mówimy o wojsku, a właściwie o żołnierskich personaliach, zwykle mamy na myśli wielkich dowódców czy wspaniałych zwycięzców. Rzadziej jednak wspomina się o ,podwykonawcach”, czyli o osobach zajmujących niższe stanowiska dowódcze, odpowiedzialnych za faktyczną realizację zadań bojowych ${ }^{1}$. W tekście chciałbym przypomnieć sylwetkę jednego z takich oficerów Wojska Polskiego - Rudolfa Ksieniewicza. Odznaczył się on męstwem

* Wydział Filozoficzno-Historyczny, Studium Doktoranckie Nauk Humanistycznych, e-mail: lolomar@wp.pl.

${ }^{1}$ W tekście użyto następujących skrótów: ap - akta personalne, CAW-WBH - Centralne Archiwum Wojskowe - Wojskowe Biuro Historyczne w Warszawie, DP - Dywizja Piechoty, Dziennik Personalny MSWojsk. - Dziennik Personalny Ministerstwa Spraw Wojskowych, GISZ - Generalny Inspektorat Sił Zbrojnych, pp - pułk piechoty. 
w czasie wojen o granice odrodzonej Polski, poświęcając całe swe późniejsze życie służbie Rzeczypospolitej w szeregach polskiej armii. Był uczestnikiem walk w 1918 r. oraz ostatnim dowódcą garnizonu równieńskiego w 1939 r. Podpułkownik R. Ksieniewicz, służąc w armii II Rzeczypospolitej, zapłacił za to cenę najwyższą, stając się jedną z ofiar zbrodni katyńskiej. Tekst ma na celu przybliżenie sylwetki tego oficera, zapomnianego niemal całkowicie przez historię.

Rudolf Stanisław Ksieniewicz urodził się 9 stycznia 1898 r. $^{2}$ w miejscowości Kiertel na estońskiej wyspie Dago (ob. Hijumaa), stanowiącej wówczas część imperium rosyjskiego. Był synem Józefa i Anny z domu Rehesaar. Z racji miejsca urodzenia oprócz języka polskiego znał również doskonale język rosyjski i estoński. Młody Rudolf w 1904 r. przeniósł się z rodzicami, dwiema siostrami oraz dwoma braćmi na ląd stały, do miasta Hapsal (ob. Haapsalu, około $100 \mathrm{~km}$ na południowy zachód od Tallina), gdzie pracował ojciec. Tam też w 1905 r. rozpoczął naukę w początkowej szkole ludowej, którą ukończył dwa lata później, po czym kontynuował edukację w szkole miejskiej w tejże miejscowości. Rok 1908 poważnie skomplikował życie rodziny, gdyż jego ojciec został zwolniony z pracy z powodu, jak pisał sam Rudolf w swoim życiorysie z 1921 r., polskiej narodowości. Nie mogąc znaleźć innego zajęcia pozwalającego na utrzymanie rodziny, rodzice zdecydowali o przeniesieniu się w głąb Rosji - do Tuły, gdzie Józef Ksieniewicz znalazł w końcu nową pracę (nie udało się ustalić jaką). Ze względu na dużą odległość przeprowadzka pochłonęła wszystkie oszczędności państwa Ksieniewiczów, przez co nie było ich stać na opłacenie nauki dzieci w lepszych szkołach. W tej sytuacji 10-letni Rudolf podjął w Ufie naukę w bezpłatnej szkole ludowej, którą ukończył w $1911 \mathrm{r}$. Z powodu kłopotów finansowych rodziny młody Rudolf nie kontynuował edukacji w gimnazjum, gdyż rodzinie ledwo starczyło pieniędzy na utrzymanie. Przez kolejne cztery lata uczęszczał do Szkoły Miejskiej przy Instytucie Nauczycielskim w Ufie 3 .

Rozpoczęta w 1914 r. I wojna światowa przyniosła poważne zmiany w życiu młodego Rudolfa, gdyż (w wieku 17 lat) w maju 1915 r. - aby ulżyć finansowo rodzinie - wstąpił ochotniczo do armii rosyjskiej. Trudno stwierdzić, czy już wówczas planował związać całe swoje dalsze życie z zawodową służbą wojskową, lecz niewątpliwie zadecydowało o tym następnych kilka lat. Początkowo, 2 lipca 1915 r. otrzymał przydział do szkoły podoficerskiej batalionu zapasowego 144 pp, gdzie był szykanowany ze względu na polską narodowość (o czym sam ponownie

${ }^{2}$ W dokumentach znajdujących się w teczce personalnej Rudolfa Ksieniewicza można spotkać także inną datę urodzin: 28 XII 1897 r. (wynika to z różnicy między kalendarzem juliańskim a gregoriańskim) i 11 I 1898 r. Kwestię daty urodzin R. Ksieniewicza wyjaśniono w 1934 r., podając w Dzienniku Personalnym MSWojsk. datę 9 I 1898 r. - vide: Dziennik Personalny MSWojsk., 26 I 1934, nr 2, s. 27.

${ }^{3}$ Curriculum vitae kapitana Rudolfa Ksieniewicza spisane 10 X 1921 r., CAW-WBH, ap Rudolf Ksieniewicz, sygn. ap 7869, karty bez paginacji; oraz Karta ewidencyjna z 10 X 1927 r., ibidem, karty bez paginacji. 
wspomina we wspomnianym życiorysie). Trudno jednak stwierdzić, na czym owe szykany polegały. Trzy tygodnie później został przeniesiony (20 lipca) do Szkoły Chorążych w Peterhofie, którą ukończył po czterech miesiącach, uzyskując 15 listopada stopień chorążego. Niebawem otrzymał przydział do 50 Syberyjskiego Pułku Strzelców, w którym 6 grudnia 1915 r. objął stanowisko młodszego oficera w 6 kompanii strzeleckiej. Przez kolejne miesiące w szeregach tego pułku brał udział w walkach na froncie rosyjsko-niemieckim na terenie dzisiejszej Estonii. Dnia 3 lipca 1916 r. został ranny nad rzeką Kekau (pod Rygą). Rana okazała się na tyle poważna, że musiał odbyć dłuższe leczenie szpitalne. Po jego zakończeniu powrócił do swojej jednostki w listopadzie 1916 r. i ponownie brał udział w walkach ${ }^{4}$.

Na początku stycznia 1917 r. został przeniesiony do 3 Finlandzkiej Dywizji Strzelców, jako oficer łącznikowy. Przebywał w niej bardzo krótko, gdyż już 20 stycznia 1917 r. trafił do Polskiej Dywizji Strzelców, w której został przydzielony do 3 pułku strzelców na stanowisko młodszego oficera w 5 kompanii strzeleckiej. W kwietniu wraz z pułkiem trafił na front, biorąc udział w walkach i awansując do stopnia podporucznika. W dniach od 4 do 31 stycznia 1918 r. przebywał na urlopie wypoczynkowym w Ufie, skąd po dojściu do władzy bolszewików nie miał możliwości powrotu do I Korpusu Polskiego. Ponieważ bolszewicy często rozstrzeliwali żołnierzy Korpusu w przypadku wzięcia do niewoli, R. Ksieniewiczowi - z obawy przed taką przyszłością - nie pozostało nic innego, jak ukrywać się w rejonie Ufy przed władzą bolszewicką. Latem 1918 r. rozpoczął formowanie oddziału polskiego, w skład którego weszli inni żołnierze polskiej narodowości, również ukrywający się przed bolszewikami. Przez kilka miesięcy oddział ten prowadził walkę partyzancką z oddziałami bolszewickimi, po czym dołączył do formującej się w głębi Rosji 5 Dywizji Syberyjskiej (nazywanej też 5 Dywizją Strzelców Polskich) ${ }^{5}$. W jednostce tej został dowódcą 1 kompanii strzeleckiej w 1 Pułku Strzelców Polskich im. Tadeusza Kościuszki (na jego bazie w Drugiej Rzeczypospolitej sformowano 82 pp). Pułk ten formował się na pograniczu wschodniej Rosji i Syberii od czerwca 1918 r. z licznie zgłaszających się do niego ochotników, będących zazwyczaj dawnymi polskimi jeńcami z armii niemieckiej i austro-węgierskiej, jak również Polaków mieszkających na Syberii, będących często wnukami polskich zesłańców po powstaniu styczniowym ${ }^{6}$. Powstaniu jednostki sprzyjało również to, że w połowie 1918 r. ważniejsze miasta Syberii oraz znajdujące się tam linie kolejowe były wolne od bolszewików. Pierwszym miejscem koncentracji pułku była właśnie Ufa,

${ }^{4}$ Curriculum vitae kapitana Rudolfa Ksieniewicza spisane 10 X 1921 r., CAW-WBH, ap. Rudolf Ksieniewicz, sygn. ap 7869, karty bez paginacji.

${ }^{5}$ O historii 5 Dywizji Strzelców Polskich vide: H. Bagiński, Wojsko polskie na wschodzie 1914-1920, Warszawa 1921, s. 535-598.

${ }^{6}$ F. Dind orf-A n k ow ic z, Zarys historji wojennej 82-go syberyjskiego pułku piechoty, Warszawa 1929, s. 3. 
gdzie kierowano powstające w okolicznych miejscowościach kolejne kompanie. Pierwszy rozkaz 1 Pułku Strzelców Polskich im. T. Kościuszki wydany został 1 lipca 1918 r. Dynamiczny rozwój sytuacji na froncie nie pozwalał jednak na normalne szkolenie, gdyż do walk trzeba było wysyłać ledwo co zorganizowane poszczególne kompanie ${ }^{7}$.

W takich okolicznościach w sierpniu 1918 r. ppor. R. Ksieniewicz wyjechał wraz ze swoją kompanią na front w okolice Jekaterynburga ${ }^{8}$, walcząc w oderwaniu od swojego pułku aż do lutego $1919 \mathrm{r}$. W tym czasie jego pododdział stoczył szereg walk z bolszewikami, zyskując sławę i szacunek dla dzielnego żołnierza polskiego. W marcu 1919 r. ${ }^{9}$ kompania R. Ksieniewicza dołączyła w końcu do własnego pułku i wraz z nim walczyła nadal przeciwko bolszewikom. Za swoją odwagę w trakcie samodzielnych walk wspomnianej kompanii R. Ksieniewicz otrzymał po wojnie Order Virtuti Militari V klasy o numerze $7702^{10}$. We wniosku odznaczeniowym podkreślano, że był R. Ksieniewicz jednym z pierwszych organizatorów Wojska Polskiego na Syberii. Doceniono również to, że przez dłuższy czas walczył w oderwaniu od macierzystej jednostki, staczając wiele walk z oddziałami Armii Czerwonej. W końcu - jak podkreślono we wniosku: „[...] powraca z kompanią do pułku, przyprowadza żołnierza bitnego, pełnego poświęceń, silnego moralnie, zbudowanego przykładem dowódcy"11. W trakcie walk awansowany został na porucznika i kapitana za waleczność okazaną w bojach z bolszewikami ${ }^{12}$. Uhonorowanie R. Ksieniewicza za jego dzielną postawę żołnierską poparł dowódca 5 Dywizji Strzelców Polskich, płk Kazimierz Rumsza i dowódca WP na Syberii, płk Walerian Czuma ${ }^{13}$.

Od maja 1919 r. 1 Pułk Strzelców Polskich im. T. Kościuszki stacjonował w garnizonie Nowonikołajewskim (dziś Nowosybirsk). Służbę garnizonową przerwało rozszerzanie się wpływów bolszewickich na Syberii, co spowodowało, że pułk został latem tego roku skierowany do thumienia probolszewickiego powstania na Syberii ${ }^{14}$. Sytuacja pogarszała się jednak z każdym miesiącem, a oddziały Armii Czerwonej zajmowały stopniowo kolejne obszary. Zmusiło to dowództwo

${ }^{7}$ D. Radziwiłło wi z, Polskie formacje zbrojne we wschodniej Rosji oraz na Syberii i Dalekim Wschodzie w latach 1918-1920, Olsztyn 2009, s. 222-224.

${ }^{8}$ F. Dindorf-Ankowicz, op. cit., s. 8.

9 Data taka została podana we wniosku o odznaczenie R. Ksieniewicza Orderem Virtuti Militari, jednak F. Dindorf-Ankowicz podaje, że powrót 1 kompanii nastąpił 6 II 1919 r. (F. D in dorf-Ankowicz, op. cit., s. 19).

${ }^{10}$ Dziennik Personalny MSWojsk., 19 VIII 1922, nr 27, s. 614.

11 Wniosek na odznaczenie orderem „Virtuti Militari” w myśl Uchwały Kapituły Tymczasowej z 23 I 1920 r. kpt. Rudolfa Ksieniewicza, CAW-WBH, Kolekcja Virtutti Militari, VM 6959-74, Rudolf Ksieniewicz, k. 6.

${ }^{12}$ Kwestionariusz z 14 III 1934 r., CAW-WBH, Kolekcja Virtutti Militari, VM 6959-74, Rudolf Ksieniewicz, k. 4.

${ }^{13}$ Kwestionariusz z 14 III 1934 r., CAW-WBH, Kolekcja Virtutti Militari, VM 6959-74, Rudolf Ksieniewicz, k. 7.

${ }^{14}$ F. Dindorf-Ankowicz, op. cit., s. 19-20. 
5 Dywizji Strzelców Polskich do wydania rozkazu do odwrotu w kierunku wschodnim. W grudniu 1919 r. por. R. Ksieniewicz wraz z podległą mu kompanią znalazł się w tylnej straży cofającej się dywizji. Przewaga bolszewików była jednak zbyt duża, by oderwać się od nieprzyjaciela. Dnia 10 stycznia 1920 r. 5 Dywizji Strzelców Polskich została przez nich osaczona i zmuszona do kapitulacji w rejonie stacji kolejowej Klukwiennaja (ob. Ujar) ${ }^{15}$. Jak wielu innych polskich oficerów, por. R. Ksieniewcz trafił do niewoli bolszewickiej i przez wiele miesięcy był więziony w obozach pracy przymusowej, najpierw w Omsku, a później w Tule.

W niewoli bolszewickiej przebywał niemal dwa lata i dopiero 3 października 1921 r. - w ramach akcji wymiany jeńców - powrócił do Polski ${ }^{16}$. Nie mając przy sobie dokumentów, trafił do obozu izolacyjnego w Dęblinie w celu potwierdzenia tożsamości i przebiegu swej służby w 5 Dywizji Strzelców Polskich. Zajęło to kilka miesięcy, lecz pozwoliło por. R. Ksieniewiczowi na kontynuowanie swej służby wojskowej w armii odrodzonej Rzeczypospolitej.

Pod koniec 1921 r. otrzymał nowy przydział do III batalionu 78 pp w Baranowiczach (pułk ten wchodził w skład 20 DP), gdzie objął stanowisko dowódcy 8 kompanii strzeleckiej. W listopadzie tego roku płk Karol Hausser, dowódca wspomnianego pułku, tak charakteryzował R. Ksieniewicza: „Charakter wyrobiony, ustalony, szczery, bardzo stanowczy. Inteligentny. Wykształcenie ogólne, ze względu ukończonych tylko 4 klas szkoły miejskiej - niewystarczające, zawodowe dostateczne - usprawiedliwione 19-miesięczną niewolą bolszewicką. Podczas krótkiego, dotychczasowego pobytu w pułku okazał dużo zamiłowania i zainteresowania dla zawodu wojskowego. W służbie nadzwyczaj gorliwy, sumienny i dokładny. Stara się usilnie braki wykształcenia zawodowego uzupełnić. Zachowanie poza służbą wzorowe, towarzyski i koleżeński. Wyrobi się na bardzo dobrego oficera" $"$.

Dnia 10 lutego 1922 r. R. Ksieniewicz został przeniesiony do rezerwy, lecz trudno ustalić, jaka była tego przyczyna ${ }^{18}$. Znalazłszy się poza wojskiem, musiał na nowo ułożyć swoje życie. Warto dodać, że od prawie czterech lat był już żonaty $\mathrm{z}$ panną Smirnową ${ }^{19}$, z którą pobrał się 28 grudnia 1918 r. $^{20}$ Wraz z żoną powrócił do Polski, gdzie przyszły na świat dwie córki: Izabela Janina (ur. 9 września 1923 r.) i Olga Maria Anna (ur. 28 grudnia 1930 r.) ${ }^{21}$.

\footnotetext{
${ }^{15}$ Vide: H. B a gińs ki, op. cit., s. 580-587.

${ }^{16}$ Kwestionariusz z 14 III 1934 r., CAW-WBH, Kolekcja Virtutti Militari, VM 6959-74, Rudolf Ksieniewicz, k. 4.

${ }^{17}$ Karta ewidencyjna z 1921 r., CAW-WBH, ap Rudolf Ksieniewicz, sygn. ap 7869, karty bez paginacji.

18 Tymczasowa karta zwolnienia do rezerwy z 10 II 1922 r., CAW-WBH, ap Rudolf Ksieniewicz, sygn. ap 7869, karty bez paginacji.

${ }^{19}$ Imienia nie udało się ustalić.

${ }^{20}$ Rozkaz nr 156 z 13 VII 1938 r., CAW-WBH, 45 pp, sygn. I.320.45.13, karty bez paginacji.

${ }^{21}$ Kwestionariusz z 14 III 1934 r., CAW-WBH, Kolekcja Virtutti Militari, VM 6959-74, Rudolf Ksieniewicz, k. 2.
} 
Po opuszczeniu szeregów wojska wstąpił do Policji Państwowej i otrzymał stopień starszego przodownika (odpowiednik starszego sierżanta w wojsku), nie udało się ustalić, w jakiej miejscowości pracował. Nowe zajęcie nie spełniało zapewne oczekiwań R. Ksieniewicza, gdyż już w marcu 1922 r. wystąpił do władz wojskowych z prośbą o wcielenie go do korpusu oficerów zawodowych wojska, motywując to tym, że chciał się poświęcić służbie wojskowej i służyć w 82 pp. Poparcia w tej sprawie udzielił mu ówczesny dowódca tego pułku, mjr Franciszek Dindorf-Ankowicz, którego znał jeszcze z lat swej służby w 1 Pułku Strzelców Polskich na Syberii, gdzie był on dowódcą batalionu, w którym służył R. Ksieniewicz. Major F. Dindorf-Ankowicz tak popierał starania R. Ksieniewicza w sprawie jego ponownego przyjęcia do zawodowej służby wojskowej: „Oficer wysokiej wartości ideowej, pierwszy organizator wojska polskiego na Syberii. Energiczny, bojowo doświadczony, znakomity wychowawca i dowódca"22.

Zapewne dzięki temu poparciu po niemal pół roku został ostatecznie przyjęty do zawodowej służby wojskowej. Dnia 9 października 1922 r. otrzymał przydział do wspomnianego 82 pp stacjonującego w Brześciu nad Bugiem (pułk ten wchodził w skład 30 DP). Początkowo objął w nim stanowisko dowódcy 3 kompanii CKM, lecz już dwa miesiące później został z dniem 22 grudnia tego roku przeniesiony do 83 pp w Kobryniu (pułk ten także wchodził w skład 30 DP). Po trzyletniej służbie został z kolei przeniesiony 2 września 1925 r. do 68 pp stacjonującego we Wrześni w Wielkopolsce (pułk ten wchodził w skład 17 DP). Z pułkiem tym związał - jak pokazało jego dalsze życie - niemal cały okres swej służby wojskowej w okresie międzywojennym, gdyż w jego szeregach znajdował się aż do 1938 r. Początkowo pełnił funkcję oficera administracji materiałowej, a następnie dowódcy 5 kompanii strzeleckiej w II batalionie (batalion ten został w 1933 r. przeniesiony - jako tzw. batalion detaszowany - do Jarocina). W międzyczasie R. Ksieniewicz został awansowany na stopień majora (1929 r.), po czym objął stanowisko kwatermistrza pułku, a następnie dowódcy kolejno I i II batalionu omawianego pułku. Dwa lata przed wybuchem II wojny światowej otrzymał kolejny awans, tym razem na stopień podpułkownika ${ }^{23}$.

W trakcie służby w 68 pp Inspektor Armii gen. dyw. Edward Śmigły-Rydz tak scharakteryzował w 1932 r. ówczesnego mjr. R. Ksieniewicza: „Ksieniewicz Rudolf, dca baonu. Upór, twardy charakter. Duży zmysł taktyczny, wyszkolenie wojskowe dobre, ogólne słabe. Pedant, precyzyjny. Bardzo dobry wychowawca. Interesuje się żołnierzami. Jeden z najlepszych dców baonów w dywizji. Pracuje nad sobą. Materiał na dcę pułku. Ponad przeciętność" ${ }^{24}$. Dwa lata później,

${ }^{22}$ Podanie do MSWojsk. z 12 III 1922 r., CAW-WBH, ap. Rudolf Ksieniewicz, sygn. ap 7869, karty bez paginacji.

${ }_{23}$ R. Ry b ka, K. S te p a n, Awanse oficerskie w Wojsku Polskim 1935-1939, Kraków 2003, s. 377.

${ }^{24}$ Opinie gen. Śmigłego-Rydza o oficerach za 1932 r., Instytut Józefa Piłsudskiego w Nowym Jorku, Archiwum Józefa Piłsudskiego, Opinie Marszałka J. Piłsudskiego i marszałka E. Rydza- 
w 1934 r. wspomniany gen. dyw. E. Śmigły-Rydz pisał z kolei o mjr. R. Ksieniewiczu następująco: „Bardzo dobry linjowiec, z instynktem bojowym i temperamentem. Niedomagania podstawowego wykształcenia [podkreślone czerwienią - przyp. M.S.] dużo mu przeszkadzają. Na wojnie nadaje się na dcę pułku. Przeciętny" "25. Jak widać, mjr R. Ksieniewicz otrzymywał zazwyczaj dobrą opinię, co pozwalało mu mieć nadzieję na rychły kolejny przydział służbowy na wyższe stanowisko. Nie było to jednak takie proste i szybkie, gdyż jeszcze przez cztery lata pozostawał w szeregach 68 pp. We wrześniu 1937 r. płk dypl. Maksymilian Milan-Kamski (dowódca 17 DP) w podobnym pozytywnym tonie charakteryzował go, pisząc w piśmie skierowanym do inspektora armii gen. bryg. Antoniego Szyllinga: „Ksieniewicz Rudolf Stanisław ppłk. piech. 19.3.1937 lok. 39, dca baonu Jarocin 68 pp: Oficer średniej inteligencji. Myśli powoli, ale po powzięciu decyzji postępuje zupełnie konsekwentnie. Doskonały oficer bojowy i dobrze przygotowany taktycznie. Osobiście dobrze fachowo wyszkolony. Spokojny, zrównoważony, nie hołduje żadnym szkodliwym nałogom. W pracy sumienny i pilny, osiąga dobre wyniki i wywiera dobry wpływ na podwładnych, choć jako wychowawca suchy i trochę za szorstki. Bardzo dobry dca baonu. Może być zastępcą dcy pułku"26.

Ostatnie zdanie opinii płk. M. Milana-Kamskiego urzeczywistniło się 11 kwietnia 1938 r., gdy ppłk. R. Ksieniewicz został mianowany I zastępcą dowódcy 45 pp w Równem na Wołyniu (pułk ten wchodził w skład 13 DP) ${ }^{27}$. Po przybyciu do pułku i objęciu swych obowiązków wielokrotnie zastępował dowódcę pułku, płk. Stanisława Hojnowskiego w przypadku jego wyjazdów służbowych, urlopów czy zwolnień chorobowych. Zajmował się wtedy regulowaniem bieżącego życia jednostki, z czym dość dobrze sobie radził. Nominacja R. Ksieniewicza zbiegła się ze zmianą w organizacji pułków piechoty, która wprowadzała na stopie pokojowej stanowisko I i II zastępcy dowódcy. Drugim zastępcą zostawał dotychczasowy kwatermistrz pułku, którym w przypadku 45 pp był ppłk Zygmunt Kostkiewicz (w razie wybuchu wojny oba stanowiska miały ulec likwidacji, a zajmujący je oficerowie mieli otrzymać nowe przydziały mobilizacyjne).

Jako I zastępca dowódcy ppłk R. Ksieniewicz odpowiadał m.in. za wyszkolenie podległych mu oddziałów, opracowywanie planów szkoleniowych i kontrolę ich wykonania, a także przeprowadzał ćwiczenia pułkowe. Przykładem działalności w tym zakresie może być zarządzone przez niego indywidualne ćwiczenie

\footnotetext{
-Śmigłego o oficerach, sygn. 701/1/117, k. 152, http://archiwa.pilsudski.org/dokument.php?nonav=1 \&nrar=701\&nrzesp=1\&sygn=117\&handle=701.180/4676\&seria $=0$ (dostęp: 15 VIII 2018).

${ }^{25}$ Ibidem, k. 214.

${ }^{26}$ Pismo dowódcy 17 DP płk. Maksymiliana Milan-Kamskiego do generała do prac przy GISZ, gen. bryg. Antoniego Szyllinga z przedstawieniem krótkich opinii o oficerach sztabowych 17 DP z 29 IX 1937 r., CAW-WBH, GISZ, sygn. I.302.4.1729, karty bez paginacji.

27 Pismo Biura Personalnego MSWojsk. z 11 IV 1938 r. w sprawie mianowania oficerów sztabowych, CAW-WBH, GISZ, sygn. I.302.4.1734, karty bez paginacji.
} 
dla starszych oficerów 45 pp, wyznaczone na 20 października 1938 r. ${ }^{28}$ Natomiast z początkiem maja 1939 r., prawdopodobnie w celu wzmocnienia jedności pułku i szacunku do państwa polskiego, zarządził codzienne wieczorne apele pułku, odbywające się z udziałem orkiestry. W ich trakcie były odmawiane i śpiewane katolickie modlitwy i pieśni. Podpułkownik Ksieniewicz przewidywał również wieczorne apele miesięczne, w których udział mieli brać wszyscy oficerowie ${ }^{29}$. Nie sposób jednak stwierdzić, ile takowych apeli odbyło się przed wybuchem wojny. Rudolf Ksieniewicz zwracał również uwagę na „niedomagania” w funkcjonowaniu jednostki, w której służył, jak np. w sprawie funkcjonowania wart pułkowych. Wartownie i ich najbliższy rejon (chodnik, ustęp, korytarz) nie były utrzymywane w czystości, a przy meldowaniu wszelakich braków nieżołnierze nie podawali, kto je spowodował i w jakich okolicznościach. Rudolf Ksieniewicz zadecydował więc, że oficerowie służbowi pułku muszą każdorazowo meldować nazwiska dowódców wart, którzy nie przestrzegają regulaminów służby wartowniczej, winnych zaś miał pociągać do odpowiedzialności. Ciężko jednak stwierdzić, na ile jego zarządzenie miało „siłę sprawczą"30. Nieobce były również R. Ksieniewiczowi sprawy sportu w wojsku - w celu usprawnienia wychowania fizycznego w batalionach wyznaczył po jednym oficerze młodszym w każdym $\mathrm{z}$ batalionów na batalionowego oficera WF. Ponadto w każdej kompanii dowódcy wyznaczyć mieli po podoficerze, który miał być pomocnikiem oficera WF i miał mu przekazywać spostrzeżenia dotyczące spraw z zakresu wychowania fizycznego w jednostce. Razem z dowódcami batalionów oficerowie WF opracowywali plany zawodów pułkowych i batalionowych (na które przewidywano niedziele i święta), które musiały być każdorazowo zaakceptowane przez ppłk. R. Ksieniewicza. W zawodach tych obowiązkowo wziąć udział mieli oficerowie i podoficerowie stanu wolnego, a żonaci ochotniczo ${ }^{31}$. Podpułkownik R. Ksieniewicz, jako osoba o usposobieniu pedantycznym i precyzyjnym (na co może wskazywać przytoczona opinia E. Rydza-Śmigłego z 1932 r.), zwracał również uwagę na otoczenie w swojej jednostce. Przykładowo gdy zauważył, że roślinność porastająca budynki koszarowe była zaniedbana, zarządził ponaciąganie drutów na budynkach aż po dach, a na nich kazał przymocować młode rośliny, które miano systematycznie podlewać (nadzorować to mieli dowódcy batalionów) ${ }^{32}$.

W trakcie służby ppłk R. Ksieniewicza w 45 pp płk S. Hojnowski - w uznaniu jego wcześniejszych zasług - wystąpił z wnioskiem o nadanie mu Złotego Krzyża Zasługi. W swym wniosku tak scharakteryzował swojego podwładnego: „Brał czynny udział w organizacjach niepodległościowych, oraz w wojnie polsko-bolszewickiej. Bardzo wartościowy oficer. Pracuje z uporem nad podniesieniem

\footnotetext{
${ }^{28}$ Rozkaz nr 202 z 13 X 1938 r., CAW-WBH, 45 pp, sygn. I.320.45.13, karty bez paginacji.

${ }^{29}$ Rozkaz nr 99 z 29 IV 1939 r., CAW-WBH, 45 pp, sygn. I.320.45.14, karty bez paginacji.

${ }^{30}$ Rozkaz nr 196 z 6 X 1938 r., CAW-WBH, 45 pp, sygn. I.320.45.13, karty bez paginacji.

${ }^{31}$ Rozkaz nr 109 z 14 V 1938 r., CAW-WBH, 45 pp, sygn. I.320.45.13, karty bez paginacji.

${ }^{32}$ Rozkaz nr 144 z 28 VI 1938 r., CAW-WBH, 45 pp, sygn. I.320.45.13, karty bez paginacji.
} 
stanu wyszkolenia pułku. Już w krótkim czasie dał się poznać jako wybitny wyszkoleniowiec i pracownik" "33. Na podstawie opinii bezpośredniego przełożonego R. Ksieniewicza można przypuszczać, że podejmowane przez niego wysiłki na polu wyszkolenia i działalności pułku było znaczne i dzięki jego zaangażowaniu dawało bardzo dobre wyniki w krótkim czasie.

W trakcie swojej kariery wojskowej R. Ksieniewicz uhonorowany został nie tylko wspomnianym Orderem Virtuti Militari, lecz także odznaczeniami armii rosyjskiej, które otrzymał w czasie swej służby w tej armii (Order Świętego Stanisława III klasy z mieczami i wstęgą oraz Order Świętej Anny IV klasy z napisem za waleczność - jako odznaczenia za walkę przeciwko nieprzyjacielowi rozkazem 12 Armii z 14 sierpnia 1916 r.) oraz odznaczeniami odrodzonej Rzeczypospolitej: Krzyża Niepodległości ${ }^{34}$, Krzyża Walecznych ${ }^{35}$, Złotego Krzyża Zasługi $^{36}$, Medalu Pamiątkowego za Wojnę 1918-1921 (11 listopada 1928 r.), Medalu Dziesięciolecia Odzyskania Niepodległości (23 grudnia 1928 r.), Brązowego Medalu za Długoletnią Służbę (10 maja 1938 r.). Otrzymał także Médaille Interalliée ${ }^{37}$ (medal aliancki nadawany uczestnikom I wojny światowej po stronie Ententy) oraz Médaille commémorative de la grande guerre (Francuski Medal Pamiątkowy Wielkiej Wojny, franc. Médaille commémorative française de la grande guerre), a także Medal Pamiątkowy Wojny 1914-1918 (Médaille commémorative de la guerre 1914-1918) - francuskie odznaczenie wojskowe, brązowy medal o średnicy $30 \mathrm{~mm}$ przyznawany od 1920 r. uczestnikom I wojny światowej ${ }^{38}$.

Pokojowa praca w 45 pp ppłk. R. Ksieniewicza zakończyła się wraz z mobilizacją alarmową 13 DP w połowie sierpnia 1939 r. Wówczas to wspomniany związek taktyczny (a wraz z nim 45 pp) został zmobilizowany i wysłany transportem kolejowym na Pomorze w rejon Bydgoszczy, gdzie wszedł w skład Korpusu Interwencyjnego mającego przeciwdziałać niemieckim próbom wcielenia Gdańska do Rzeszy. Po mobilizacji dywizji i opuszczeniu przez jej pododdziały swoich pokojowych garnizonów przystąpiono w Równem do organizowania Ośrodka Zapasowego $13 \mathrm{DP}^{39}$, który miał formować uzupełnienia dla walczącej dywizji oraz bataliony marszowe 43, 44 i 45 pp. Dowódcą tego Ośrodka Zapasowego został ppłk Kazimierz Czarnecki, a jego zastępca ppłk Zygmunt Kostkiewicz (do mobilizacji II zastępca dowódcy 45 pp). Ośrodkowi Zapasowemu dywizji

33 CAW-WBH, Kolekcja Krzyża Zasługi, KZ 23-145, Rudolf Stanisław Ksieniewicz, k. 2.

34 Dziennik Personalny MSWojsk., 11 XI 1931, nr 8, s. 363.

35 Dziennik Personalny MSWojsk., 28 III 1923, nr 18, s. 210.

36 R. Ry b k a, K. S te pa n, Rocznik oficerski 1939. Stan na 23 marca 1939 r., Kraków 2006, s. 16.

37 Dziennik Personalny MSWojsk., 14 V 1925, nr 53, s. 254.

38 Dziennik Personalny MSWojsk., 19 III 1931, nr 2, s. 81.

39 Do 1 IX 1939 r. bataliony zapasowe 44 i 45 pp znajdowały się we Włodzimierzu Wołyńskim. Z początkiem 1939 r. zostały one przekształcone w Kadrę Zapasową Piechoty we Włodzimierzu Wołyńskim, której dowódcą został ppłk Kazimierz Czarnecki. W. Jarn o, 13. Dywizja Piechoty w wojnie 1939 r., Warszawa 2012, s. 197. 
podlegały również Ośrodki Zapasowe 43 pp (w Dubnie) oraz 44 i 45 pp oraz 13 pal (w Równem). Po opuszczeniu Równego przez oddziały 13 DP w mieście pozostało wielu oficerów służących w niej przed mobilizacją, którzy otrzymali przydziały do Ośrodka Zapasowego. Jednym z nich był ppłk R. Ksieniewicz, który został niebawem dowódcą garnizonu w Równem. Natomiast ppłk Z. Kostkiewicz oprócz stanowiska zastępcy dowódcy Ośrodka Zapasowego 13 DP objął najprawdopodobniej także dowództwo Ośrodka Zapasowego $45 \mathrm{pp}^{40}$.

Po wybuchu II wojny światowej sytuacja na froncie polsko-niemieckim szybko się pogarszała, co skłoniło polskie dowództwo do podjęcia przygotowań do zorganizowania improwizowanej obrony na obszarze Wołynia na bazie formowanych naprędce oddziałów zapasowych. Na Wołyń zaczęły również napływać wycofujące się instytucje wojskowej administracji centralnej (m.in. w Łucku przez kilka dni przebywał rząd polski, a w Równem Dowództwo Saperów i Dowództwo Broni Pancernej) oraz oficerowie z różnych ewakuowanych na wschód Dowództw Okręgów Korpusów (np. 11 września do Łucka przybył gen. Aleksander Narbutt-Łuczyński, dowódca Okręgu Korpusu nr V Kraków).

W połowie września w Równem znaleźli się również oficerowie znani w mieście ze swej wcześniejszej służby w tutejszym garnizonie, jak np. gen. bryg. Adam Korytkowski (ostatni dowódca OK nr IV Łódź, wcześniej przez kilka lat dowódca Wołyńskiej Brygady Kawalerii) czy płk dypl. Józef Ćwiertniak (stojący do 24 sierpnia 1939 r. na czele 13 DP). Nie wykazali oni jednak aktywności w kwestii zaangażowania się w sprawy przygotowania tutejszego garnizonu do obrony ${ }^{41}$. Kres tym działaniom przyniósł 17 września, gdy Armia Czerwona wkroczyła zbrojnie do Polski. Już pierwszego dnia walk miasto zostało w godzinach porannych zaatakowane przez sowieckie samoloty, które szybko odleciały ostrzelane ogniem polskich przeciwlotniczych karabinów maszynowych. Następne godziny przeznaczono na ewakuację garnizonu w kierunku Włodzimierza Wołyńskiego, co okazało się słusznym posunięciem, gdyż jeszcze w godzinach popołudniowych do Równego dotarły pierwsze sowieckie jednostki (batalion rozpoznawczy 45 Dywizji Strzelców z kilkunastoma czołgami). Kilka godzin później, w godzinach wieczornych miasto znalazło się pod całkowitą kontrolą sowiecką, a pozostali w nim polscy żołnierze trafili do niewoli ${ }^{42}$.

Los okazał się tragiczny dla oficerów z Ośrodka Zapasowego 13 DP i podległych mu Ośrodków Zapasowych 43, 44 i 45 pp. Jako jeńcy zostali przez Sowietów wywiezieni na wschód. Tam większość z nich znalazła się w obozie w Kozielsku lub Starobielsku. Podpułkownik R. Ksieniewicz opuścił Równe

40 Ibidem, s. 198.

${ }^{41}$ M. F ałd ow s k a, Okoliczności wzięcia polskich oficerów do niewoli radzieckiej po 17 września 1939 r., [w:] Wrzesień 1939. Wojna na dwa fronty, red. J. Gmitruk, W. Włodarkiewicz, Warszawa 2010, s. 555.

${ }^{42}$ W. Jarno, op. cit., s. 199-203; R. S zawłowski, Wojna polsko-sowiecka 1939, t. I, Warszawa 1997, s. 272-273. 
17 września i próbował przedostać się do walczących jeszcze polskich oddziałów, lecz dwa dni później dostał się w bliżej nieznanych okolicznościach do niewoli radzieckiej. Początkowo uwięziono go w obozie przejściowym w Równem, skąd 28 marca 1940 r. wywieziono go do Kijowa ${ }^{43}$, gdzie niebawem został zamordowany w bliżej nieznanych okolicznościach. Oprawcy sowieccy zabili go najprawdopodobniej w kijowskim więzieniu NKWD. Jego nazwisko znalazło się na tzw. Ukraińskiej Liście Katyńskiej z 1994 r. ${ }^{44}$, szczątki ofiar tej części zbrodni pochowane są na Polskim Cmentarzu Wojennym w Kijowie-Bykowni. Podobny tragiczny los spotkał większość oficerów garnizonu Równe, którzy we wrześniu 1939 r. dostali się do niewoli sowieckiej. Zostali oni w większości zamordowani wiosną 1940 r. w Katyniu (jak np. ppłk Z. Kostkiewicz ${ }^{45}$ ), a ci, co trafili do Starobielska - w więzieniu NKWD w Charkowie.

Artykuł ten jest przyczynkiem do biografii ppłk. R. Ksieniewicza, kawalera Orderu Virtuti Militari, który poświęcił całe swoje życie Polsce i armii Drugiej Rzeczypospolitej. Nie dane mu było dowodzić we wrześniu 1939 r. jednostką liniową, lecz pozostał na tyłach, mając zapewnić właściwe funkcjonowanie garnizonu Równe po agresji niemieckiej. Jednak niebawem nastąpiła również agresja sowiecka, która przypieczętowała los Polski, a ppłk R. Ksieniewicz za swą wierność ojczyźnie zapłacił najwyższą cenę. Dlatego też warto przypomnieć jego sylwetkę jako jednej z tysięcy ofiar zbrodni sowieckiej na polskich oficerach, by pamięć o nim nie zaginęła.

\section{Bibliografia}

\section{Źródea ARCHIWALNE}

Centralne Archiwum Wojskowe - Wojskowe Biuro Historyczne w Warszawie [CAW-WBH]

Akta personalne Rudolfa Ksieniewicza, sygn. ap 7869.

Kolekcja Krzyża Zasługi, KZ 23-145, Rudolf Stanisław Ksieniewicz.

Kolekcja Virtutti Militari, VM 6959-74, Rudolf Ksieniewicz.

Generalny Inspektorat Sił Zbrojnych, sygn. I.302.4.1729, I.302.4.1734.

45 pp, sygn. I.320.45.13, I.320.45.14.

Instytut Józefa Piłsudskiego w Nowym Jorku

Archiwum Józefa Piłsudskiego, Opinie Marszałka J. Piłsudskiego i marszałka E. Rydza-Śmigłego o oficerach, t. 701/1/117.

${ }^{43}$ K. B an as ze k, W. Ro man, Z. S a w i c ki, Kawalerowie Orderu Virtuti Militari w mogiłach katyńskich, Warszawa 2000, s. 160.

${ }^{44}$ Listy katyńskiej ciag dalszy. Straceni na Ukrainie. Lista obywateli polskich zamordowanych na Ukrainie na podstawie decyzji biura politycznego WKP(b) i naczelnych władz państwowych ZSRR z 5 marca 1940 roku, Warszawa 1994, s. 49.

${ }^{45}$ K. B anaszek, W. Roman, Z. S awicki, op. cit., s. 146. 


\section{ŹRÓDEA DRUKOWANE}

Dzienniki Personalne Ministerstwa Spraw Wojskowych, nr 27 z 1922 r.; nr 18 z 1923 r.; nr 53 z 1925 r.; nr 2 i 8 z 1931 r.; nr 2 z 1934 r.

\section{Opracowania}

Bagiński H., Wojsko polskie na wschodzie 1914-1920, Warszawa 1921.

Banaszek K., Roman W., Sawicki Z., Kawalerowie Orderu Virtuti Militari w mogiłach katyńskich, Warszawa 2000.

Dindorf-Ankowicz F., Zarys historji wojennej 82-go syberyjskiego putku piechoty, Warszawa 1929.

Fałdowska M., Okoliczności wzięcia polskich oficerów do niewoli radzieckiej po 17 września 1939 r., [w:] Wrzesień 1939. Wojna na dwa fronty, red. J. Gmitruk, W. Włodarkiewicz, Warszawa 2010, s. 541-560.

Jarno W., 13. Dywizja Piechoty w wojnie 1939 r., Warszawa 2012.

Listy katyńskiej ciag dalszy. Straceni na Ukrainie. Lista obywateli polskich zamordowanych na Ukrainie na podstawie decyzji biura politycznego WKP(b) i naczelnych władz państwowych ZSRR z 5 marca 1940 roku, Warszawa 1994.

Radziwiłłowicz D., Polskie formacje zbrojne we wschodniej Rosji oraz na Syberii i Dalekim Wschodzie w latach 1918-1920, Olsztyn 2009.

Rybka R., Stepan K., Awanse oficerskie w Wojsku Polskim 1935-1939, Kraków 2003.

Rybka R., Stepan K., Rocznik oficerski 1939. Stan na 23 marca 1939 r., Kraków 2006.

Szawłowski R., Wojna polsko-sowiecka 1939, t. I, Warszawa 1997.

\section{MAREK STEFAŃSKI}

\section{Lieutenant Colonel Rudolf Ksieniewicz (1898-1940) - bachelor of the order Virtuti Militari and a victim of the Katyn massacre. A contribution to the biography}

\footnotetext{
The article presents a figure of Lieutenant Colonel Rudolf Ksieniewicz, one of the officers of 1 the army of the Second Polish Republic. He born on the Estonian island Dago, after moving with his family, he is in the depths of Russia. In order to relieve parents financially, he joins to the Russian Army. Going up the career ladder, he becomes one of the organizers of the Polish Army on Siberia. As a result of battles he gets into Bolshevik slavery, in which he remains until October 1921. In free Poland, he continues his military career, reaching the rank of lieutenant colonel and rising to the position of first deputy commander in the $45^{\text {th }}$ Infantry Regiment in Rowne in Wołyń. In 1939, after the mobilization of the $13^{\text {th }}$ infantry division, he remained in the garrison, of which he became the commandant. After the entry of the Red Army on September 17, he was taken prisoner, in the spring of 1940 he was murdered.
}

Keywords: Rudolf Ksieniewicz, Stefan Hojnowski, 45 ${ }^{\text {th }}$ Infantry Regiment, Polish Army, Katyn massacre, Rowne, history of Rowne, Katyn. 